\title{
STRATEGI PENGEMBANGAN DESA WISATA BERBASIS MASYARAKAT (Studi Kasus: Desa Lebakmuncang, Kecamatan Ciwidey, Kabupaten Bandung)
}

\author{
Fajar Giri Pratama ${ }^{1}$ Ganjar Kurnia $^{2}$ \\ Program Studi Agribisnis, Fakultas Pertanian, Universitas Padjadjaran ${ }^{12}$ \\ fajargiripratama@gmail.com ${ }^{1}$,ganjark@unpad.ac.id ${ }^{2}$
}

\begin{abstract}
Lebakmuncang village is one of tourism-village that has been set by government of Bandung regency - West Java through SK regent of Bandung Regency - West Java. Tourism-village of Lebakmuncang is offering tourism like agroecoeducation and cultural orientation which developed by local community. Lebakmuncang tourism village have obstacles in running the tourism village, it's caused by the visitors that visited it was decreasing, so the source of income of local community only came from farming, trading, and breeding. That needs a development strategy to impelemented in Lebakmuncang tourism village and to get the most suitable option using the SWOT (Strength, Weakness, Opportunity, and Threat) Analysis. The analysis result of factors internal and external be processed using SWOT Matrix. The result from SWOT Matrix be generating some strategies which can be implemented by Lebakmuncang tourism village. Determinations of strategies in developing Lebakmuncang tourism village are to create a new tour package by maintaining existing ones of utilizing potential that is still not maximized; maintain, to conserve and adding facility and potency which already have; Direct Interaction tourism activities are strengthened in terms of environment; fixing the rod, adding direction's board and cashier of ticketing; implementing of developing and use technology and do the cooperation or partnering with travel agency to promotion; adding services, quality and facility which already have; and do the cooperation or partnering with another tourism attaraction.
\end{abstract}

Keyword: Development Strategy, Tourism-Village, Community Based, SWOT

\begin{abstract}
ABSTRAK
Desa Lebakmuncang merupakan salah satu desa wisata yang sudah ditetapkan oleh Pemerintah Kabupaten Bandung - Jawa Barat melalui SK Bupati Kabupaten Bandung Jawa Barat. Desa Wisata Lebakmuncang menawarkan wisata Agroekoedukasi dan Orientasi Budaya yang dikembangkan oleh masyarakat setempat. Desa Wisata Lebakmuncang mengalami kendala dalam menjalankan desa wisata nya yaitu jumlah wisatawan yang berkunjung terus mengalami penurunan sehingga pendapatan masyarakat setempat hanya dari bertani, berdagang, dan beternak saja. Diperlukan suatu strategi pengembangan yang diterapkan Desa Wisata Lebakmuncang agar mendapatkan strategi yang cocok dengan menggunakan Analisis SWOT (Strength, Weakness, Opportunity, Threat). Hasil analisis faktor-faktor internal dan faktor-faktor eksternal tersebut diolah dengan menggunakan Matriks SWOT. Hasil dari pengolahan tersebut menghasilkan beberapa strategi yang dapat diterapkan oleh Desa Wisata Lebakmuncang. Hasil penentuan strategi dalam pengembangan Desa Wisata Lebakmuncang adalah membuat paket wisata baru dengan mempertahankan yang sudah ada dan memanfaatkan potensi yang masih belum dimaksimalkan; menjaga, melestarikan, dan menambah fasilitas dan potensi yang sudah ada; kegiatan wisata Direct Interaction lebih diperkuat pada segi lingkungan; memperbaiki jalan, menambah petunjuk arah dan tiket masuk atau karcis masuk; menerapkan perkembangan dan penggunaan teknologi dan melakukan kerjasama atau
\end{abstract}


bermitra dengan biro perjalanan wisata untuk promosi; meningkatkan atau menambah pelayanan, kualitas, dan fasilitas yang sudah ada; dan melakukan kerjasama atau bermitra dengan tempat wisata lain.

\section{PENDAHULUAN}

Indonesia memiliki kekayaan alam dan hayati yang sangat beragam yang dapat dijadikan berbagai produk yang bisa menjadi andalan perekonomian bangsa Indonesia ${ }^{1}$. Saat ini Indonesia sedang meningkatkan pembangunan di berbagai sektor mulai dari sektor ekonomi sampai dengan sektor pertanian. Pariwisata menjadi sektor unggulan di Indonesia karena memberikan dampak positif bagi masyarakat salah satunya dalam hal penyediaan lapangan pekerjaan. Selain itu, pariwisata saat ini sedang digalakkan oleh pemerintah dikarenakan penghasil devisa negara disamping sektor migas. Sektor pariwisata menjadi penyumbang devisa yang cukup besar bagi Indonesia di tahun 2018, yaitu sebesar US\$ 20 miliar. Angka tersebut mengalami kenaikan sebesar 20\% jika dilihat dari tahun 2017 yang sekitar US\$ 16,8 miliar ${ }^{2}$. Dengan begitu,

\footnotetext{
${ }^{1}$ Ernaldi, Edgardi Muhammad. 2010. Analisis Strategi Pengembangan Agrowisata Perkebunan Teh Gunung Mas PTPN VIII Bogor, Jawa Barat. Fakultas Ekonomi dan Manajemen. Institut Pertanian Bogor.

${ }^{2}$ Simorangkir, Eduardo. 2018. Pariwisata Jadi Andalan Penyumbang Devisa US\$ 20 Miliar. Diakses pada tanggal 4 Mei 2018 melalui < https://finance.detik.com/berita-ekonomi-bisnis/d3844660/pariwisata-jadi-andalan-penyumbangdevisa-us-20-miliar>
}

sektor pariwisata dapat berpotensi untuk berkembang di Indonesia. Selain pembangunan di sektor pariwisata, masyarakat diharapkan dapat pula memelihara kelestarian kekayaan alam dan hayati agar tidak rusak.

Sektor pariwisata di Indonesia tidak hanya menarik perhatian wisatawan nusantara saja tetapi juga wisatawan mancanegara pun tidak sedikit yang tertarik pada pariwisata Indonesia. Bahkan wisatawan mancanegara tersebut menjadikan Indonesia sebagai destinasi pariwisata. Pariwisata adalah salah satu sektor yang dapat memberikan pengaruh yang cukup besar dalam perekonomian negara. Faktor-faktor yang mempengaruhi pendapatan atau perolehan devisa negara dari kontribusi sektor pariwisata adalah pajak. Pajak tersebut didapat ketika wisatawan mancanegara tersebut melakukan transaksi perjalanan wisata. Tidak hanya wisatawan asing, wisatawan nusantara pun terkena pajak pariwisata. Sumbangan devisa negara yang diberikan oleh sektor pariwisata cukup tinggi karena pajak yang didapat dari sektor pariwisata cukup besar. 
Tabel 1. Perkembangan Jumlah Perjalanan Wisatawan Nusantara, Rata-Rata Perjalanan,

Pengeluaran Per Perjalanan 2009 - 2013

\begin{tabular}{|r|c|r|r|r|}
\hline Tahun & $\begin{array}{c}\text { Perjalanan } \\
\text { (ribuan) }\end{array}$ & $\begin{array}{c}\text { Rata-Rata } \\
\text { Perjalanan (kali) }\end{array}$ & $\begin{array}{c}\text { Pengeluaran Per } \\
\text { Perjalanan (ribu Rp) }\end{array}$ & $\begin{array}{c}\text { Total Pengeluaran } \\
\text { (triliun Rp) }\end{array}$ \\
\hline 2009 & 229.731 & 1,92 & 600,30 & 137,91 \\
\hline 2010 & 234.377 & 1,92 & 641,76 & 150,41 \\
\hline 2011 & 236.752 & 1,94 & 679,58 & 160,89 \\
\hline 2012 & 245.290 & 1,98 & 704,68 & 172,85 \\
\hline 2013 & 250.036 & 1,92 & 711,26 & 177,84 \\
\hline
\end{tabular}

Sumber: Pusdatin Kemenparekraf \& BPS

Jumlah wisatawan nusantara setiap tahunnya mengalami kenaikan (Tabel 1). Salah satu faktor yang membuat wisatawan nusantara mengalami kenaikan setiap tahunnya adalah masyarakat mengalami peningkatan taraf perekonomian kehidupannya. Peningkatan atau kenaikan jumlah wisatawan setiap tahunnya tentu akan memperngaruhi tingkat pendapatan pemerintah jika dilihat dari sektor pariwisata. Pada tahun 2009, jumlah wisatawan nusantara berada pada angka 229.731 orang. Pada tahun 2011, jumlah wisatawan nusantara mengalami kenaikan yang cukup besar yaitu berada pada angka 236.752 orang. Pada tahun 2013 kembali mengalami kenaikan menjadi 250.036 orang. Angka tersebut mengalami kenaikan yang cukup besar terhitung mulai tahun 2009 .

Konsep back to nature yang menjadi trend wisata di Indonesia mulai berkembang. Hal tersebut terbukti dari banyaknya wisata dengan konsep back to nature bermunculan diberbagai daerah seperti Bandung, Malang, Bali, hingga Papua. Ciwidey memiliki beberapa tempat wisata yang menarik. Salah satu objek wisata yang menarik dan memiliki potensi untuk berkembang yaitu Desa Wisata Lebakmuncang. Desa Wisata Lebakmuncang ini berada di Kecamatan Ciwidey, Kabupaten Bandung. Desa Wisata Lebakmuncang merupakan Wisata Agroekoedukasi dan Orientasi Budaya yang dikembangkan oleh masyarakat sekitar melalui pembinaan yang diberikan oleh pemerintah. Desa Wisata Lebakmuncang juga sering menjadi tempat mahasiswa melakukan kegiatan KKN (Kuliah Kerja Nyata).

Desa Wisata Lebakmuncang menawarkan paket wisata berbasis pendidikan, diantaranya Direct Interaction (mengikuti keseharian masyarakat), Agricultural Education (edukasi bercocok tanam), Outdoor 
Activity Program (jungle trekking dan mengenal alam sekitar), Cultural Education (mengenal kesenian dan budaya), dan Education Specialties (mengenal makanan khas tradisional). Desa Wisata Lebakmuncang menyediakan Villa atau Homestay.

Akan tetapi jika dilihat beberapa bulan kebelakang, Desa Wisata Lebakmuncang tidak terlihat sering dikunjungi oleh para wisatawan. Hal tersebut dipicu oleh banyaknya objek wisata di daerah tersebut. Tidak sedikit para wisatawan yang berpikir bahwa kegiatan bercocok tanam dan kebudayaan-kebudayaan sudah

\section{METODE PENELITIAN}

Penelitian ini menggunakan pendekatan kualitatif. Input data kualitatif berdasarkan dengan persepsi manusia atau responden dengan bantuan kuesioner. Data kualitatif akan diolah menggunakan Analisis SWOT (Strength, Weakness, Opportunity, dan Threat). Hasil analisis disimpulkan melalui penjabaran hasil analisis yang berbentuk kualitatif. Teknik penelitian yang digunakan oleh peneliti adalah teknik penelitian studi kasus. Studi kasus adalah teknik penelitian yang mendalam tentang individu, satu kelompok, satu organisasi, ketinggalan zaman. Maka dari itu, pengelola agrowisata di Desa Lebakmuncang harus memiliki strategi agar tidak kalah dengan objek wisata lain. Penelitian ini akan dilakukan di Desa Lebakmuncang, Kecamatan Ciwidey, Kabupaten Bandung. Melalui penelitian ini, peneliti akan memperdalam lagi tinjauan mengenai potensi agrowisata dari desa wisata. Berdasarkan uraian diatas, penulis tertarik melakukan penelitian mengenai "Strategi Pengembangan Desa Wisata (Studi Kasus: Desa Lebakmuncang, Kecamatan Ciwidey, Kabupaten Bandung)".

satu program, kegiatan, dan sebagainya dalam waktu yang tertentu. Tujuannya untuk memperoleh deskripsi yang utuh dan mendalam. Teknik penelitian ini akan memperoleh data dari hasil wawancara, observasi, dan dokumentasi.

Alat analisis yang digunakan adalah SWOT (Strength, Weakness, Opportunity, dan Threat) merupakan alat yang digunakan untuk membuat dan menyusun faktor-faktor strategis bagi perusahaan. Tujuan dari matriks ini yaitu untuk menganalisis faktor-faktor internal dari perusahaan dan faktor-faktor eksternal. Faktor internal mempunyai 
tujuan untuk mengetahui kekuatan dan kelemahan dari perusahaan. Faktor eksternal mempunyai tujuan untuk mengetahui peluang dan ancaman yang akan datang. Ada beberapa tahapan dalam melakukan Analisis SWOT antara lain: (1) Identifikasi Faktor-Faktor Internal dan Eksternal; (2) Penyusunan Kuesioner; dan (3) Analisis Data.

Hasil penilaian tersebut akan menghasilkan beberapa faktor yaitu strength (kekuatan), weakness (kelemahan), opportunity (peluang), dan threat (ancaman). Setelah itu, kelompok faktor tersebut akan melakukan analisis matriks SWOT. Matriks SWOT dapat menggambarkan secara jelas bagaimana faktor eksternal meliputi peluang dan ancaman yang dihadapi desa yang disesuaikan dengan faktor internal meliputi kekuatan dan kelemahan yang dimiliki desa.

\section{HASIL DAN PEMBAHASAN}

\subsection{Analisis Lingkungan Internal}

\subsubsection{Pertanian}

Sektor pertanian berperan penting dalam keberlangsungan agrowisata. Komoditas yang ditanam di Desa Wisata Lebakmuncang bermacam-macam, yaitu padi, kopi, teh, seledri, bawang merah, tomat, stroberi, dan lain-lain. Namun dalam menjalankan agrowisata, Desa Wisata Lebakmuncang hanya menggunakan seledri, bawang merah, tomat, dan stroberi untuk keperluan agrowisata. Budidaya seledri, bawang merah, tomat, dan stroberi pun berbedabeda.

\subsubsection{Pemasaran}

Sistem pemasaran dari Desa Wisata Lebakmuncang adalah menawarkan suatu produk yang memiliki ciri khas tersendiri dari Desa Wisata Lebakmuncang. Promosi yang dilakukan oleh Desa Wisata Lebakmuncang masih kurang gencar. Desa Wisata Lebakmuncang melakukan promosi hanya melalui brosur dan website, tetapi masih kurang gencar dan aktif.

\subsubsection{Keuangan}

Sistem manajemen keuangan yang diterapkan oleh Desa Wisata Lebakmuncang sudah terstruktur dengan baik. Data keuangan Desa Wisata Lebakmuncang diatur tertulis menggunakan sistem akuntansi sederhana. Setiap transaksi keluar masuk pasti langsung tercatat dengan baik di buku tersebut sehingga tidak terjadi kesalahpahaman dalam mengatur keuangan di Desa Wisata Lebakmuncang.

\subsubsection{Produksi dan Operasi}

Edukasi di bidang pertanian 
sangat penting dikarenakan Indonesia adalah negara agraris yang memiliki lahan pertanian yang harus dimanfaatkan dengan baik. Maka dari itu untuk mengelola lahan pertanian dengan baik harus mempelajari bagaimana cara mengelola lahan pertanian dengan baik dan benar. Selain itu untuk memperkenalkan budaya tradisional, Desa Wisata Lebakmuncang memperagakan dan para wisatawan dapat mempelajari kesenian tradisional tersebut. Makanan khas tradisional juga dapat dirasakan dan dapat mempelajari cara membuatnya oleh para wisatawan.

\subsubsection{Sumber Daya Manusia}

Sumber daya manusia yang dimiliki oleh Desa Wisata Lebakmuncang adalah masyarakat desa itu sendiri. Jadi apabila Desa Wisata Lebakmuncang sedang tidak ada pengunjung, maka masyarakat desa tersebut melakukan kegiatan sehari-hari mereka sesuai dengan apa yang mereka lakukan, seperti bertani, berdagang, beternak, dan lain sebagainya.

\subsubsection{Sistem Informasi dan Manajemen}

Walaupun sistem informasi manajemen yang sudah diterapkan oleh Desa Wisata Lebakmuncang ini dapat dikatakan cukup dalam mendukung kegiatan kerja, tetapi masih ada kelemahan yang dirasakan dalam sistem informasi manajemen yang terdapat di Desa Wisata Lebakmuncang. Sistem pendataan dan pemesanan hanya dilakukan dengan cara pencatatan atau pembukuan secara manual. Sistem informasi manajemen akan lebih mudah dilakukan jika menggunakan sistem komputerisasi dengan program atau aplikasi khusus.

\subsection{Analisis Lingkungan Eksternal}

\subsubsection{Analisis Lingkungan Jauh}

Faktor eksternal seperti peluang dan ancaman akan mempengaruhi jalan atau keberlangsungan usaha dan tidak dapat dikendalikan secara langsung oleh perusahaan. Analisis lingkungan jauh memiliki faktor-faktor yang pada dasarnya terlepas dari perusahaan tetapi dapat mempengaruhi keberlangsungan usaha. Faktor-faktor tersebut, diantaranya: (1) Faktor Ekonomi; (2) Faktor Sosial dan Budaya; (3) Faktor Politik; dan (4) Faktor Teknologi.

\subsubsection{Analisis Lingkungan Industri}

Lingkungan industri berada disekitar usaha dan berpengaruh secara langsung terhadap operasional perusahaan. Aspek kunci dari lingkungan perusahaan adalah industri walaupun lingkungan yang relevan sangat luas 
mencakup kekuatan sosial dan ekonomi.

Aspek-aspek tersebut, diantaranya: (1)

Ancaman masuknya pendatang baru; (2)

Ancaman produk pengganti; (3)

Kekuatan tawar-menawar pemasok; (4)

Kekuatan tawar-menawar pembeli; dan

(5) Tingkat persaingan.

\subsection{Strategi}

Pengembangan

Agrowisata

\subsubsection{Aksesibilitas}

Aksesibilitas adalah kemudahan sebuah tempat wisata untuk dikunjungi dan memiliki jalan yang dapat dilalui oleh kendaraan. Lokasi wisata yang dapat dijangkau atau ditempuh oleh para wisatawan baik secara individu atau perorangan maupun rombongan serta lokasi wisata yang layak, aman, nyaman, dan tersedianya sarana penunjang transportasi. Berbagai fasilitas fisik yang dimiliki oleh Desa Wisata Lebakmuncang memumpuni untuk kegiatan wisata. Hanya saja ada beberapa yang masih memerlukan pemeliharaan atau perbaikan, seperti ada beberapa titik jalan di Desa Wisata Lebakmuncang yang masih rusak.

\subsubsection{Akomodasi}

Akomodasi adalah kemudahan para wisatawan untuk mendapatkan tempat penginapan yang bersih dan layak sebagai tempat bermalam. Desa Wisata
Lebakmuncang menyediakan beberapa Home Stay untuk para wisatawan sebagai tempat bermalam. Desa Wisata Lebakmuncang memiliki berbagai jenis rumah, diantaranya rumah permanen, rumah semi permanen, rumah panggung, dan rumah dinding yang terbuat dari kayu.

\subsubsection{Atraksi}

Atraksi adalah kemudahan para wisatawan dalam melihat atau merasakan atraksi yang khas di tempat wisata. Desa Wisata Lebakmuncang menawarkan dua jenis atraksi, yaitu budaya dan alam. Para wisatawan dapat melihat serta mempelajari kesenian Indonesia dan mengetahui serta membuat makanan khas tradisional. Selain itu, Desa Wisata Lebakmuncang menawarkan kelestarian alam seperti kegiatan bercocok tanam dan kegiatan jungle trekking.

\subsubsection{Aktivitas}

Paket wisata ditawarkan Desa Wisata Lebakmuncang, diantaranya: (1) Direct Interaction; (2) Agricultural Education; (3) Outdoor Activity Program; (4) Cultural Interaction; dan (5) Education Specialties.

\subsubsection{Amenitas}

Amenitas adalah fasilitas-fasilitas lain yang menunjang perjalanan wisata yang diperlukan oleh para wisatawan 
seperti mesin ATM, rumah makan, toko atau warung, jaringan internet, dan lainlain. Fasilitas-fasilitas penunjang ini sangat penting bagi wisatawan selama berkunjung ke Desa Wisata Lebakmuncang.

\subsection{Kegiatan Wisata}

\subsubsection{Direct Interaction}

Wisatawan akan melakukan keseharian masyarakat Desa Wisata Lebakmuncang baik dari segi pertanian, lingkungan, dan budaya. Wisatawan akan berperan sebagai masyarakat Desa Wisata Lebakmuncang. Kegiatan Direct Interaction dalam satu hari dapat dilakukan 3 kali, yaitu pagi, siang/sore, dan malam. Namun wisatawan hanya dapat melakukan 2 kali kegiatan dikarenakan wisatawan harus melakukan kegiatan wisata lainnya.

\subsubsection{Agricultural Education}

Wisatawan akan melakukan kegiatan dari segi pertanian. Petani Desa Wisata Lebakmuncang akan memberikan edukasi kepada wisatawan tentang bagaimana cara menanam, memelihara, memanen, dan memasarkan. Selain diberikan edukasi oleh petani, wisatawan dapat langsung terjun ke lahan untuk bercocok tanam. Komoditas yang digunakan untuk kegiatan wisata ini adalah seledri, bawang merah, tomat, dan stroberi.

\subsubsection{Outdoor Activity Program}

Wisatawan akan melakukan kegiatan jungle trekking, mengenal alam sekitar, konservasi alam, dan ngaliwet. Kegiatan wisata ini bertujuan untuk mengetahui dan menjaga alam.

\subsubsection{Cultural Interaction}

Wisatawan dapat menyaksikan atraksi yang diperagakan oleh para seniman dan memainkan keseniankesenian tersebut. Kesenian yang dimaksud adalah Degung, Bangkong Reang, dan Jaipong. Wisatawan didampingi oleh seniman dalam mencoba memainkan kesenian-kesenian tersebut.

\subsubsection{Education Specialties}

Kegiatan wisata ini bertujuan untuk memperkenalkan kepada wisatawan mengenai makanan khas tradisional. Ada beberapa makanan khas tradisional yang akan menjadi bagian dari kegiatan wisata ini, diantaranya Ranginang, Rangening, Saroja, dan Dodol Stroberi. Wisatawan dapat melihat pembuatan makanan khas tradisional dengan dibimbing oleh masyarakat, membuat, dan mencicipi makanan khas tradisional tersebut. Apabila ada wisatawan yang ingin membawa makanan khas tradisional sebagai buah tangan, mereka dapat membelinya di 
masyarakat yang menjual makanan khas tradisional tersebut.

\subsection{Jalur Wisata}

Desa Wisata Lebakmuncang berada di wilayah wisata. Tidak sedikit objek-objek wisata maupun non-wisata dapat dilihat ketika melewati jalan menuju Desa Wisata Lebakmuncang. Berikut ini adalah Peta Jalur Wisata Desa Wisata Lebakmuncang.

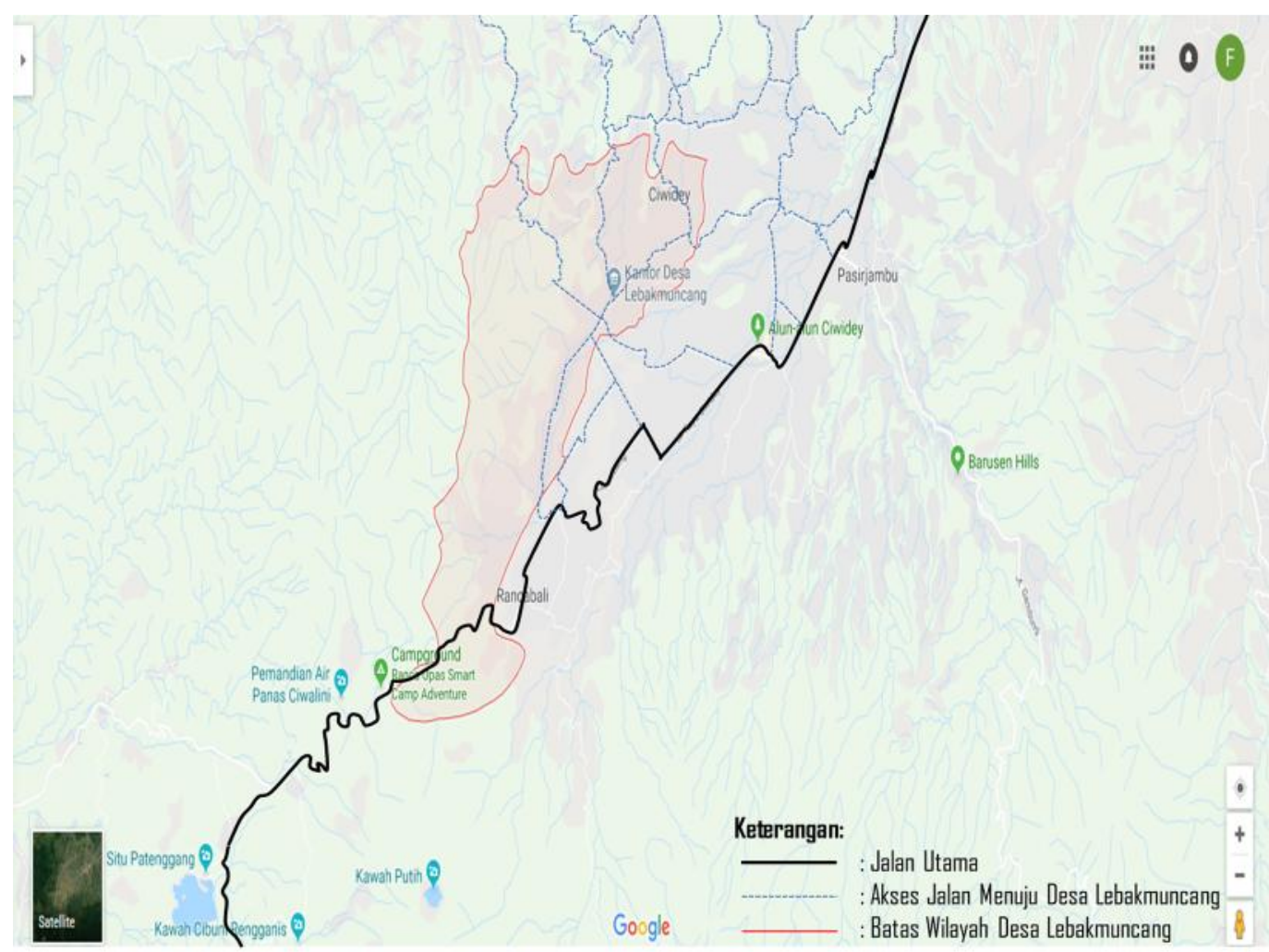

Gambar 1. Jalur Wisata Desa Wisata Lebakmuncang

Menurut Gambar 1., apabila memulai melalui jalan utama dari arah Soreang (atas), akan melewati beberapa objek wisata dan kuliner. Diantaranya Taman Love Soreang, Restoran Sindang Reret, dan camilan khas Ciwidey yaitu Kalua Jeruk di sepanjang jalan mulai dari Restoran Sindang Reret hingga AlunAlun Ciwidey. Tidak jauh dari Alun-Alun Ciwidey, para wisatawan akan menemui pertigaan yang dimana jika berbelok ke kanan akan menuju arah Desa Wisata Lebakmuncang. Namun jika tetap lurus akan menuju kearah daerah wisata lainnya.

Apabila memulai melalui jalan utama dari arah Cianjur (bawah), akan melewati beberapa objek wisata dan kuliner. Diantaranya Kawah Cibuni Rengganis, Situ Patenggang, Glamping Lakeside Rancabali, Pemandian Air Panas Ciwalini, Pemandian Air Panas 
Cimanggu, Kawah Putih, Ranca Upas, Ciwidey Valley Resort, kedai kopi luwak di sepanjang jalan utama, stroberi petik sendiri di sepanjang jalan utama, dan Happy Farm Ciwidey. Setelah melewati Happy Farm Ciwidey, para wisatawan akan menemui pertigaan yang dimana jika berbelok ke kiri akan menuju arah Desa Wisata Lebakmuncang. Namun apabila lurus akan menuju ke arah Kota Bandung.

\subsection{Identifikasi Kekuatan dan}

Kelemahan

\subsubsection{Kekuatan}

Kekuatan yang dimiliki oleh Desa Wisata Lebakmuncang, diantaranya: (1) Agricultural Education sebagai edukasi pertanian; (2) Cultural Interaction sebagai wadah melestarikan budaya; (3) Education Specialties sebagai kegiatan wisata kuliner; (4) Outdoor Activity Program sebagai kegiatan di alam terbuka; (5) Kelestarian alam yang sejuk dan asri; (6) Lokasi wisata yang strategis; (7) Infrastruktur yang baik; (8) Memiliki fasilitas penginapan; (9) Jaringan internet yang memadai; dan (10) Sumber daya manusia yang ahli.

\subsubsection{Kelemahan}

$\begin{array}{lrrr} & \text { Kelemahan } & \text { yang dimiliki oleh } \\ \text { Desa } & \text { Wisata } & \text { Lebakmuncang, } \\ \text { diantaranya: (1) Direct Interaction }\end{array}$

kurang menarik; (2) Beberapa titik jalan yang masih rusak; (3) Petunjuk arah yang kurang; (4) Jalan yang kurang luas; (5) Promosi masih belum intensif; (6) Tidak adanya tiket atau karcis masuk; (7) Sistem pemesanan melalui internet belum tersedia; dan (8) Pendataan pemesanan masih belum menggunakan sistem komputerisasi.

\subsection{Identifikasi Peluang dan Ancaman}

\subsubsection{Peluang}

Peluang yang dapat dimaksimalkan oleh Desa Wisata Lebakmuncang, diantaranya: (1) Trend wisata back to nature sedang naik; (2) Potensi ternak yang masih belum dimaksimalkan; (3) Jumlah wisatawan yang terus bertambah setiap tahunnya; (4) Akses jalan yang mudah karena berada di jalur wisata; (5) Perkembangan teknologi yang memudahkan untuk transaksi dan promosi; dan (6) Adanya biro perjalanan wisata yang dapat membantu promosi.

\subsubsection{Ancaman}

Ancaman yang dapat dihindari oleh Desa Wisata Lebakmuncang, diantaranya; (1) Banyaknya agrowisata dan desa wisata yang muncul di sekitar daerah tersebut; (2) Persaingan dalam bisnis agrowisata yang relatif tinggi; (3) Ciri khas yang unik dari agrowisata atau desa wisata lain; (4) Pola pikir para 
wisatawan yang menganggap pertanian

kuno; dan (5) Kesadaran para wisatawan untuk menjaga objek wisata.

\subsection{Analisis Matriks SWOT}

Tabel 2. Hasil Matriks SWOT Desa Wisata Lebakmuncang

\begin{tabular}{|c|c|c|}
\hline EKSTERNAL & $\begin{array}{l}\text { Kekuatan (S): } \\
\text { 1. Agricultural } \\
\text { Education sebagai } \\
\text { edukasi pertanian } \\
\text { 2. Cultural Interaction } \\
\text { sebagai wadah } \\
\text { melestarikan budaya } \\
\text { 3. Education Specialties } \\
\text { sebagai kegiatan } \\
\text { wisata kuliner Activity } \\
\text { 4. Outdoor sebagai } \\
\text { Program alam } \\
\text { kegiatan di } \\
\text { terbuka yan } \\
\text { 5. Kelestarian alam yang } \\
\text { sejuk dan asri } \\
\text { 6. Lokasi wisata yang } \\
\text { strategis } \\
\text { 7. Infrastruktur yang baik } \\
\text { 8. Memiliki fasilitas } \\
\text { penginapan } \\
\text { 9. Jaringan internet yang } \\
\text { memadai } \\
\text { 10. Sumber daya } \\
\text { manusia yang ahli }\end{array}$ & $\begin{array}{l}\text { Kelemahan (W): } \\
\text { 1. Direct Interaction } \\
\text { kurang menarik } \\
\text { 2. Beberapa titik jalan } \\
\text { yang masih rusak } \\
\text { 3. Petunjuk arah yang } \\
\text { kurang } \\
\text { 4. Jalan yang kurang } \\
\text { luas } \\
\text { 5. Promosi masih belum } \\
\text { intensif } \\
\text { 6. Tidak adanya tiket } \\
\text { atau karcis masuk } \\
\text { 7. Sistem pemesanan } \\
\text { melalui internet } \\
\text { belum tersedia } \\
\text { 8. Pendataan man } \\
\text { pemesanan masih } \\
\text { belum menggunakan } \\
\text { sistem komputerisasi }\end{array}$ \\
\hline $\begin{array}{l}\text { Peluang (O): } \\
\text { 1. Trend wisata back to nature } \\
\text { sedang naik } \\
\text { 2. Potensi ternak yang masih } \\
\text { belum dimaksimalkan } \\
\text { 3. Jumlah wisatawan yang } \\
\text { terus bertambah setiap } \\
\text { tahunnya } \\
\text { 4. Akses jalan yang mudah } \\
\text { karena berada di jalur } \\
\text { wisata teknologi } \\
\text { 5. Perkembangan untuk } \\
\text { yang memudahkan unta } \\
\text { transaksi dan promosi } \\
\text { 6. Adanya biro perjalanan } \\
\text { wisata yang dapat } \\
\text { membantu promosi }\end{array}$ & $\begin{array}{l}\text { Strategi SO: } \\
\text { - Membuat paket wisata } \\
\text { baru dengan } \\
\text { mempertahankan yang } \\
\text { sudah ada dan } \\
\text { memanfaatkan potensi } \\
\text { yang masih belum } \\
\text { dimaksimalkan. (S1, } \\
\text { S2, S3, S4, O2, O6) } \\
\text { - Menjaga, } \\
\text { melestarikan, dan } \\
\text { menambah fasilitas } \\
\text { dan potensi yang } \\
\text { sudah ada. (S5, S6, S7, } \\
\text { S8, S9, S10, O1, O3, } \\
\text { O4, O5) }\end{array}$ & $\begin{array}{l}\text { Strategi WO: } \\
\text { - Kegiatan wisata } \\
\text { Direct Interaction } \\
\text { lebih diperkuat pada } \\
\text { segi lingkungan. } \\
\text { (W1, O4) } \\
\text { - Memperbaiki jalan, } \\
\text { menambah petunjuk } \\
\text { arah dan tiket atau } \\
\text { karcis masuk (W3, } \\
\text { W4, W6, O1, O3, } \\
\text { O4) } \\
\text { - Menerapkan } \\
\text { perkembangan dan } \\
\text { penggunaan } \\
\text { teknologi dan } \\
\text { melakukan kerjasama } \\
\text { atau bermitra dengan } \\
\text { biro perjalanan }\end{array}$ \\
\hline
\end{tabular}




\begin{tabular}{|c|c|c|}
\hline & & $\begin{array}{l}\text { wisata untuk promosi } \\
\text { (W5, W7, W8, O5, } \\
\text { O6) }\end{array}$ \\
\hline $\begin{array}{l}\text { Ancaman (T): } \\
\text { 1. Banyaknya agrowisata dan } \\
\text { desa wisata yang muncul } \\
\text { disekitar daerah tersebut } \\
\text { 2. Persaingan dalam bisnis } \\
\text { agrowisata yang relatif } \\
\text { tinggi } \\
\text { 3. Ciri khas yang unik dari } \\
\text { agrowisata atau desa wisata } \\
\text { lain } \\
\text { 4. Pola pikir para wisatawan } \\
\text { yang menganggap pertanian } \\
\text { kuno } \\
\text { 5. Kesadaran para wisatawan } \\
\text { untuk menjaga objek wisata }\end{array}$ & $\begin{array}{l}\text { Strategi ST: } \\
\text { - Meningkatkan atau } \\
\text { menambah pelayanan, } \\
\text { kualitas, dan fasilitas } \\
\text { yang sudah ada. (S1, } \\
\text { S2, S3, S4, S5, S6, S7, } \\
\text { S8, S9, S10, T1, T2, } \\
\text { T3, T4, T5) }\end{array}$ & $\begin{array}{l}\text { Strategi WT: } \\
\text { - Melakukan } \\
\text { kerjasama atau } \\
\text { bermitra dengan } \\
\text { tempat wisata lain. } \\
\text { (W1, W2, W3, W4, } \\
\text { W5, W6, W7, W8, } \\
\text { T1, T2, T3, T4, T5) }\end{array}$ \\
\hline
\end{tabular}

\subsection{Implikasi Paket Wisata}

Paket wisata yang dimiliki Desa

Wisata Lebakmuncang masih kurang jika dilihat dari potensi wisata yang dimiliki.
Paket wisata yang dapat dilaksanakan ada tiga jenis, yaitu Tipe Bronze (1 Hari), Tipe Silver (2 Hari 1 Malam), dan Tipe Gold (3 Hari 2 Malam).

Tabel 3. Paket Wisata Bronze (1 Hari)

\begin{tabular}{|c|c|c|}
\hline Hari & Waktu & Kegiatan \\
\hline Hari Pertama & $07.00-07.30$ & Penyambutan Wisatawan \\
\cline { 2 - 3 } & $07.30-11.30$ & Agricultural Education \\
\cline { 2 - 3 } & $11.30-12.30$ & Istirahat \\
\cline { 2 - 3 } & $12.30-14.30$ & Education Specialties \\
\cline { 2 - 3 } & $14.30-15.30$ & Istirahat \\
\cline { 2 - 3 } & $15.30-17.00$ & Cultural Interaction \\
\cline { 2 - 3 } & 17.00 & Pelepasan Wisatawan \\
\hline
\end{tabular}

Tabel 4. Paket Wisata Silver (2 Hari 1 Malam)

\begin{tabular}{|c|c|c|}
\hline Hari & Waktu & Kegiatan \\
\hline Hari Pertama & $07.00-07.30$ & Penyambutan Wisatawan \\
\cline { 2 - 3 } & $07.30-08.15$ & Mengantar Wisatawan ke Home Stay \\
\cline { 2 - 3 } & $08.15-11.15$ & Agricultural Education \\
\cline { 2 - 3 } & $11.15-12.30$ & Istirahat \\
\cline { 2 - 3 } & $12.30-15.00$ & Fun Livestock \\
\cline { 2 - 3 } & $15.00-15.45$ & Istirahat \\
\cline { 2 - 3 } & $15.45-17.30$ & Education Specialties \\
\cline { 2 - 3 } & $17.30-19.00$ & Istirahat \\
\cline { 2 - 3 } & $19.00-22.00$ & Cultural Interaction \\
\hline
\end{tabular}




\begin{tabular}{|l|c|c|}
\hline & $22.00-07.00$ & Tidur Malam \\
\hline \multirow{3}{*}{ Hari Kedua } & $07.00-08.00$ & Free Time \\
\cline { 2 - 3 } & $08.00-08.30$ & Persiapan Wisatawan Pulang \\
\cline { 2 - 3 } & 08.30 & Pelepasan Wisatawan \\
\hline
\end{tabular}

Tabel 5. Paket Wisata Gold (3 Hari 2 Malam)

\begin{tabular}{|l|c|c|}
\hline Hari & Waktu & Kegiatan \\
\hline Hari Pertama & $07.30-08.00$ & Penyambutan Wisatawan \\
\cline { 2 - 3 } & $08.00-08.45$ & Mengantar Wisatawan ke Home Stay \\
\cline { 2 - 3 } & $08.45-11.45$ & Agriculture Education \\
\cline { 2 - 3 } & $11.45-13.00$ & Istirahat \\
\cline { 2 - 3 } & $13.00-16.00$ & Fun Livestock \\
\cline { 2 - 3 } & $16.00-19.00$ & Istirahat \\
\hline \multirow{5}{*}{ Hari Kedua } & $19.00-22.00$ & Cultural Interaction \\
\cline { 2 - 3 } & $22.00-07.00$ & Tidur Malam \\
\cline { 2 - 3 } & $07.00-11.00$ & Outdoor Activity Program \\
\cline { 2 - 3 } & $11.00-12.30$ & Istirahat \\
\cline { 2 - 3 } & $12.30-15.00$ & Direct Interaction \\
\cline { 2 - 3 } & $15.00-16.00$ & Istirahat \\
\cline { 2 - 3 } & $16.00-17.30$ & Education Specialties \\
\cline { 2 - 3 } & $17.30-19.00$ & Istirahat \\
\cline { 2 - 3 } & $19.00-22.00$ & Direct Interaction \\
\cline { 2 - 3 } & $22.00-07.00$ & Tidur Malam \\
\cline { 2 - 3 } & $07.00-08.00$ & Free Time \\
\cline { 2 - 3 } & $08.00-08.30$ & Persiapan Wisatawan Pulang \\
\cline { 2 - 3 } & 08.30 & Pelepasan Wisatawan \\
\hline
\end{tabular}

\section{KESIMPULAN DAN SARAN}

\subsection{Kesimpulan}

1. Berdasarkan hasil pengamatan tentang penghambat yang menyebabkan sedikitnya kunjungan wisatawan, beberapa faktor penghambat seperti tidak menariknya kegiatan wisata Direct Interaction, jalan yang rusak di beberapa titik, jalan yang kurang luas, petunjuk arah yang masih kurang, tidak adanya tiket atau karcis masuk, faktor manajemen masih kurang terstruktur seperti pemesanan belum menggunakan sistem komputerisasi, sistem pemesanan melalui internet belum tersedia, dan promosi masih belum intensif.

2. Berdasarkan hasil penelitian tentang strategi pengembangan desa wisata, kegiatan wisata yang menyenangkan dan bermanfaat, kelestarian alam yang sejuk dan asri, infrastruktur yang baik, 
lokasi yang strategis, fasilitas penginapan, jaringan internet yang memadai serta bimbingan dari masyarakat yang sudah ahli merupakan potensi serta kekuatan yang dapat dimaksimalkan untuk mengelola suatu desa wisata.

3. Berdasarkan hasil pengolahan dengan menggunakan Analisis SWOT (Strength, Weakness, Opportunity, dan Threat) dapat diketahui bahwa tujuan strategi pengembangan yang tepat adalah membuat paket wisata baru dengan mempertahankan yang sudah ada dan memanfaatkan potensi yang masih belum dimaksimalkan; menjaga, melestarikan, dan menambah fasilitas dan potensi yang sudah ada; kegiatan wisata Direct Interaction lebih diperkuat pada segi lingkungan; memperbaiki jalan, menambah petunjuk arah dan tiket atau karcis masuk; menerapkan perkembangan dan penggunaan teknologi dan melakukan kerjasama atau bermitra dengan biro perjalanan wisata untuk promosi; meningkatkan atau menambah pelayanan, kualitas, dan fasilitas yang sudah ada; dan melakukan kerjasama atau bermitra dengan tempat wisata lain.

\subsection{Saran}

1. Desa Wisata Lebakmuncang perlu menambahkan beberapa unit rumah panggung, menyusun paket wisata baru, menambahkan kegiatan wisata, menjaga kelestarian lingkungan, memanfaatkan kekuatan yang dimiliki seperti jaringan internet yang memadai untuk keperluan promosi melalui internet, memperbaiki jalan yang rusak, menambahkan petunjuk arah dan tiket atau karcis, dan melakukan kerjasama atau bermitra dengan biro perjalanan wisata.

2. Desa Wisata Lebakmuncang perlu menambahkan komoditas pertanian sebagai bagian dari kegiatan wisata. Kegiatan wisata di Desa Wisata Lebakmuncang dapat ditambahkan dengan kegiatan beternak. Desa Wisata Lebakmuncang dapat menambahkan fasilitas seperti sebuah taman yang berisi tanaman-tanaman untuk tempat para wisatawan berfoto-foto. Sebelum melakukan kegiatan, 
Desa Wisata Lebakmuncang

harus memberikan edukasi

tentang betapa pentingnya

kebersihan bagi kehidupan.

Melakukan kerjasama atau

bermitra dengan agrowisata lain.

\section{DAFTAR PUSTAKA}

Ernaldi, Edgardi Muhammad. 2010. Analisis Strategi Pengembangan
Agrowisata Perkebunan Teh Gunung Mas PTPN VIII Bogor, Jawa Barat. Fakultas Ekonomi dan Manajemen. Institut Pertanian Bogor.

Simorangkir, Eduardo. 2018. Pariwisata Jadi Andalan Penyumbang Devisa US\$ 20 Miliar. Diakses pada tanggal 4 Mei 2018 melalui <https://finance.detik.com/beritaekonomi-bisnis/d-

3844660/pariwisata-jadi-andalanpenyumbang-devisa-us-20-

miliar> 